DOI: $10.11649 / \mathrm{abs} .2016 .012$

\title{
Галина Кутьрёва-Чубаля
}

Технико-Гуманитарная Академия в г. Бельско-Бяла

(Akademia Techniczno-Humanistyczna w Bielsku-Białej)

Бельско-Бяла (Bielsko-Biała)

\section{Лексика песенных зачинов в белорусской свадьбе: семантика, структурные трансформации (на примере одной группы текстов)}

В ареалогическом изучении этнопесенного языка ведущих жанров белорусского фольклора мы основываемся (а) на методе типологической систематизации текстов и напевов в их тесном структурном взаимодействии, (б) на анализе изменений инвариантных форм в пространстве и времени. В процессе синхронного многоуровневого картографирования элементов песенной лексики обнаруживаются местные либо, шире, зональные «разночтения» в бытовании, исполнении типовых напевов. Особенно ярко это проявляется при сопоставлении песен единой тематики и, при более узкой классификации, с одним формульным текстом. Однако число вариантов не безгранично, и образуются они не хаотично. Внутри силлаборитмических типовых песенных комплексов можно заметить определённые закономерности варьирования, тенденции изменений, свойственные конкретным зонам внутри макроареалов. В связи с этим актуальным представляется введение понятия динамической типологи и в изучение народной песни.

Синкретическая природа песенного языка, онтогенетическая взаимосвязь, как минимум, двух его параметров - вербального текста и напева - предопреде- 
ляет необходимость последовательного изучения корреляций этих составляющих в каждом отдельном типологическом корпусе песен различных жанровых циклов. Нередко именно в характере корреляций кроется источник тех или иных трансформаций как текста, так и напева.

В таком разрезе интересно, на наш взгляд, провести сопоставление двух монотематических групп инципитов (зачинов) свадебных песен ${ }^{1}$, почти идентичных в лексическом плане. Песни символизируют прощание невесты с родительским домом. В зачинах же зафиксирован момент прибытия «поезда» жениха, то есть самого Молодого и его свиты - сватов. На каждой свадьбе есть одна либо две кульминационные песни, которые поются участницами свадьбы со стороны невесты и служат сигналом к началу сцены прощания Молодой с родителями, с домом. В соответствующем свадебном томе академической серии «Беларуская народная творчасць» тематическая подборка текстов с интересующими нас зачинами помещена составителями в разделе «Маладая просіиь не аддаваць яе замуж» (Грынблат \& Фядосік, 1983, с. 511-561). При написании данной статьи нами проанализировано около 110 вариантов текстов из личного аудиоархива ${ }^{2}$ и из опубликованных материалов (см. перечень в Приложении). Это образцы из 65 районов Беларуси, двух поветов Белосточчины (Хайнувка и Семятыче) и района Краславы в Латвии. В совокупности варианты образуют лексико-поэтическую парадигму, общим звеном которой является монотематический зачин. В наиболее часто встречающихся вариантах передаётся характеристика звука, шума и источника звука, шума по езда жен и ха. Сгруппируем тексты по начальному глаголу:

- Застукалі кованы вазы на дварэ

- Застучалі каваны колы у полі

- Да застучэлі вараны коні ў падвор'i

- Застучэлі куты колы на дворы

- Застукылі коні-калёсы на дварэ

- Застукачелі вараныя коні на дварэ

- Да застукалі, да загрукалі на дварэ

- Загрукалі кованы вазы на дварэ

- Загрукацелі вараны коні на дварэ

- Як загрукацелі вараны коні на дварэ

- Загрукалі новыя калёсы на сяле

1 Выбор текстового материала обусловлен нашими поисками недостающих звеньев в разрушенных, неполных текстах, каковые встречаются нам в полевой практике. Речь идёт о текстах, привлёкших внимание необычными лексическими деталями, сюжетными поворотами - один из таких образцов приводится ниже.

2 Архив составляют записи 1981-2005 годов, произведённые нами в 58 районах Беларуси и приграничья, см. подробнее: Кутырёва-Чубаля, 2013, с. 99. 
- Затупалі вараныя конікі на дварэ

- Затупацелі вараныя коні на дварэ

- Зазвінелі залатыя колы на масту

- Зазвінелі залатые кольцы на дворы

- Да зазвінелі кованы колы на двары

- Зазвінелі кованы вазы на дварэ

- Дазазвінелі жалезныя колы у дворы

- Зазвінелі званкі-званочкі ў прагоне

- Ой, зарзалі вараны коні на дварэ

- Якзаржалі сівыя конікі на полі

- Зарзалі кутыл коні ў полі

- Да зарзалі сівыя коні у полі

- А заржалі конікі за дваром

- Зарзалі вараны коні за сялом

Редкий образец поэтичности зачина:

Лятуць вараныя коні ад вады,

Звіняць-бразджаць шаўкавыя павадь.

(Грынблат \& Фядосік, 1983, с. 511).

Слово «зазвінелі», помимо приведённой выше коннотации (в колокации с возами/конями), появляется также в отнесении к убранству стола - в коллокации со словами кубкі, кілішкі, чарачкі (Зазвінелі залатыя кубкі на стале), при этом инципит рифмуется с темой коней:

Зазвінелі залатыя кубкі на стале

Ой, заржалі вараныя конікі на стайні.

В данном примере мы усматриваем инверсию строк: в большинстве песен в роли инципита выступает вторая строка приведённого здесь текста. Возможно, именно из второй строки Зазвінелі залатыя кубкі/чарачкі и пр. начальный глагол заимствован для инципита «про коней». Это подтверждается расширенным - 4-сегментным - вариантом, где налицо заимствование формулы с рифмующимися начальными словами из зачинов о конях/возах. Такие примеры преобладают в данной подгруппе текстов:

Застукалі да забрацалі залатые чарачкі на стале...

Расширение строки зачина характерно для принеманской зоны (Столбцы, Новогрудок, Дятлово, Щучин, латерально Любань). Здесь наблюдается количественное увеличение сегментов в зачинах, реже во всех строфах песни, посредством добавления слогов (застукацелі/загрукацелі - вместо застукалі/ 
загрукалі), вставки сегментов (из трёхсегментной строка преобразуется в четырёхсегментную). Сравним:

- Застукацелі ; вараныя коні | на дварэ

- Застукацелі, ; загрукацелі ; вараныя коні | на дварэ

С тенденцией накопления/нагромождения текста в зачине коррелирует превалирование двигательной моторики в ритме напева. Всё это создаёт ощущение возбуждённо-приподнятого тонуса исполнения песен, семантически усиливает выражение атмосферы всеобщего ожидания, предчувствия следующего действа свадьбы, связанного с волнением невесты в момент прощания с родительским домом. Тексты, следующие после такого зачина, разворачиваются по нескольким микросюжетным версиям. Отметим два из них. Первый - минизарисовка во второй строфе деталей одежды, внешнего вида жениха и одного из сватов будущего деверя невесты (Нотный пример $1^{3}$ ):

Застукацелі жалезныя вушы на сяле,

- Выдзь, мамачка, палядзі, иі не па мяне?

У чорным адлася,$~ \check{~ ч э р в о н ы м ~ п а я с я ~-~ д з е в я р ~ т в о и ̆, ~}$

а итто у сінюм на коніку сівым - мілы твой.

Второй троп важно рассмотреть в связи с характерной тенденцией «распада» целостного текста на фрагменты, которые далее бытуют самостоятельно и имеют, соответственно, свои инципиты. Речь идёт о сюжетной парадигме, где дочь-невеста, заслышав шум поезда жениха, падает в ноги (на ногі) матери/ отцу с просьбой-мольбой (как положено по ритуалу, а изначально - не только по ритуалу) не отдавать её замуж хотя бы ещё год (Нотный пример 2)5:

Да застукалі кованы вазы на дварэ,

Да й зачула малада Ганначка у каморы.

Да й упала свайму татачку на ногі:

Не 'ддай, не 'ддай, родны татачка, й ад себе,

Не 'даай, не 'даай, родны татачка, й ад себе,

Пералетую ета леиячко й у цебе.

${ }^{3}$ Песня (всего две строфы, поскольку текст забыт исполнительницей) записана нами в Копыльском районе Минщины (принёманская зона) в 1983 году. Нотная расшифровка автора (ГКЧ).

${ }^{4}$ Вне связи с темой зачинов отметим, что среди редких - варианты текстов с упоминанием «чорнага атласу/адласу», в который одет деверь, «чорнага шоўку», которым невеста просит связать ворота (Грынблат \& Фядосік, 1983, с. 517) и не впускать Разлуку, т. е. жениха (Грынблат \& Фядосік, 1983, c. 529). Можно усмотреть здесь скрытую метафору боязни/предчувствия/нежелания/неготовности Молодой вступать в новую - незнакомую и потому кажущуюся враждебной - жизнь, в чужую семью.

${ }^{5}$ Песня записана нами в 1987 году в Любанском районе Минской обл. (переходная неманско-полесская зона). Нотная расшифровка автора (Ліцвінка \& Кутырова, 1995, с. 192). 
Ето лецечко невялікаё дзенькамі.

Ой, шчо ж бы я да пагуляла з дзеуккамі.

Ето тецечко невялікаё - адзін дзень,

Ой, хоцьь бы я шчо й пагуляла між людзей.

Ето лечечко невялікаё - нядзелька,

Ой, шчо бжа я да пагуляла, як дзеўка.

Эволюция текстов данной сюжетной группы проявляется в редукции путём отсечения вступительной части текста: песни начинаются сразу с кульминационного - как наиболее, видимо, экспрессивного с точки зрения участников свадьбы момента «падения» молодой в ноги отцу-матери. Такие варианты зафиксированы преимущественно на восточной окраине ареала основного текста: Сенно, Крупки, Борисов (Карта 1, обозначено ромбом). Зачином усечённых вариантов текста становится кульминационная строфа - начало диалога дочери с одним из родителей (либо монолога-причета). Вот несколько вариантов производных зачинов:

- Не 'ддай, не 'ддай, родны татачка, й ад себе

- Да не дай, не дай, родна маманька, ад сябе

- Не 'ддай, не 'ддай мяне, мамачка, ў чужы край

Отдельную подгруппу составляют песни с зачином-просьбой не отдавать за вдовца. К этим зачинам, в свою очередь, подбираются рифмы: броўиз - за ўдоўца,

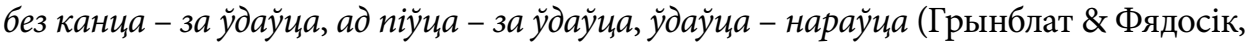
1983 , с. 550-554):

- Не аддай мяне, мамачка, за уцдауци, А й у уцдайа вялікая нараўца.

- Баліць мне галовачка і броуци, Не аддай мяне, мамачка, за уцдоуиа.

- Баліць, баліць ды й галовачка з-пад вяниа, А не аддай, мой жа татачка, за ўдаўца.

- A п'яная мая галоўка ад піуциа,

- Не дай, не дай, мамачка, мяне за уцайца.

Зачин-обращение приобретает повествовательную форму (смена глагольного наклонения):

Баліцьь жа мая галовачка без кания, Што аддаець мяне мамачка за уцдайца.

Зачины о вдовце распространены внутри макроареала полных текстов (Карта 2), преимущественно в центральной широте, с перифериями на севере (Миоры), востоке (Борисов, Березино, Кличев), латерально - на юге Брестчины (Кобрин). Таким образом, отсечённая часть первоначального варианта продолжает множиться, 
звенья его бытуют как самостоятельные произведения, со «своими» зачинами. Не случайно исходные и производные тексты в публикациях расположены не сгруппированно, а вразброс: их позиция предопределяется иными - микросюжетными - критериями (Грынблат \& Фядосік, 1983, с. 512-515, 550-561). Отделившиеся фрагменты - тексты-дериваты - постепенно также обрастают новыми словами, оборотами, рифмами, что прослеживается в подборке академического тома (Грынблат \& Фядосік, 1983, с. 558-561). Процесс образования производных текстов с их инципитами может быть описан подробнее, если привлечь к рассмотрению различные контаминационные варианты. Контаминация - один из аспектов диахронии текста: мы обнаруживаем здесь, соответственно, «иные» зачины, возникшие благодаря инверсии фрагментов, комбинаторике и т. п. Ступенчатость лексических новообразований a priori бесконечна, сродни цепной реакции.

Что касается собственно зачинов, то стадиальность их развития проявляется, помимо прочего, на лексико-морфологическом уровне, а именно в «обрастании» текста-модели (исходного инварианта) разного рода аффиксами. В частности, характерно: (а) наличие частиц ( $\partial a / \partial b l, ~ ж a)$, междометий, протетических асемантичных гласных $(i, b l, \ni)$ в начале зачинов строф либо в серединных цезурах ${ }^{6}$, (б) использование уменьшительно-ласкательных суффиксов, (в) введение микроповторов слов (не дай, не дай; баліць, баліць и т. п.). Увеличение количества слогов сопряжено с дроблением исходных слогонот на более мелкие. При этом временной каркас строк, включая зачины, остаётся, как правило, неизменным. И всё-таки зачин - наиболее уязвимая с точки зрения соблюдения структурных параметров часть строфы и песни в целом (ср. число слогов в приведённых выше текстах зачинов).

Музыкально-диалектные особенности исполнения песен с зачинами типа Застукалі, загрукалі ... проявляются в вариантности стопной ритмики. Один и тот же в основе текст в вокальной практике местных певческих школ воспроизводится неодинаково, с точки зрения ритмики и мелодического рисунка. Корень ритмических различий заключается в склонности, предпочтениях песенников из разных зон, микрозон, сёл, деревень, а иногда - различных улиц деревни пропевать известный текст в излюбленной ими стопной ритмике. В представленных в статье зачинах также отразилась специфика местных школ интонирования.

Например, в северо-западной зоне (Браславщина и прилегающие районы) в силлабической структуре зачина 4+4+3 (Застукалі сівы коні на дварэ)

6 Такое оформление цезур, вероятно, онтогенетически связано с респираторным фактором, т. е. обусловлено необходимостью взятия дыхания, однако со временем вошло в исполнительский канон. Как писал Климент Квитка, «первоначально вынужденное, превращается впоследствии в преднамеренную манеру [...], вместо физиологического момента наступает эстетический, а из физиологического явления возникает артистическая манера» (Квитка, 1973, с. 74, 71-72). 
4-сложники пропеваются в ритме антиспаста (иначе - ямбо-хорея, моры 1221); в гродненско-минском Понеманье широко бытуют диямбы (моры 1212). Здесь в большинстве певческих традиций 4-сложники чередуются с 5-сложниками различной стопной структуры. Стопы-изоморфы, взаимозаменяясь внутри строф, вносят некое дополнительное движение, лишают песню ритмической остинатности, однообразия. Наряду с этим, в этой же зоне бытуют упомянутые выше песни с моторной динамикой, в основе которой лежит иная 4-сложная стопа - дипиррихий (моры 1111, Нотный пример 1). Особенностью тектоники строк с двумя дипиррихиями (слогосостав 4+4+3) является отсутствие в них мелких цезур - маркируются лишь слоги-финалисы. Текст такой песни звучит относительно менее распевно, с некоторым уклоном в декламацию.

Важным, хотя и вторичным, фактором в создании семантического поля песни, начиная с зачина, является состав поющих. Ансамблевому исполнению присуще более строгое соблюдение ритмического канона текста и напева. В индивидуальном же исполнении одарённые песенницы/песенники поднимают поэтический текст песни на иную высоту благодаря включению элемента импровизации, однако лишь в тех фрагментах строфы, где это предполагается тектоникой напева (типичны, например, распевы акцентных слогов, орнаментальное заполнение/обыгрывание межстрочных цезур и т. п.). Есть местные школы, которым свойственно сочетание распевности и декламационности в исполнении песни (гродненско-минско-брестское пограничье с эпицентром в Дятловском районе). Яркой иллюстрацией этому могут послужить пять песен Юрья с Дятловщины (Варфаламеева, 1998, с. 43-48). Причём в большей степени это касается стилистики зачинов и начальных строф в целом. В частности, характерно «раскачивание» темпа, относительная зыбкость структуры (агогика - колебания темпа и ритма) в начале песни и постепенное, от строфы к строфе, выравнивание темпа и слогоритмики к концу песни. Не знакомый с местным певческим «почерком» фольклорист (из личного опыта) воспринимает всё это как подготовку к настоящему, «полноценному» исполнению. Однако тот же процесс повторяется с каждой новой песней.

Помимо индивидуального, важно принимать во внимание и объективный фактор, а именно предрасположенность определённых жанров песни к напевнодекламационному исполнению. Давно замечено, что есть «жанры речевой динамики» (гукание весны, жнивные) и «жанры двигательной динамики» (Елатов, 1966, с. 199), что обусловлено этнографическими особенностями культурно-бытового уклада. С точки зрения стилевой ареологии, интересны региональные оппозиции: область органичного включения речевой динамики - Понеманье, область превалирования двигательной динамики - Поднепровье и Днепро-Двинское междуречье.

В восточной Беларуси аналогичная по тематике и лексике парадигма свадебных зачинов (Карта 3) коррелирует с принципиально иной, нежели 
описанная ранее, силлабической формой: двухсегментной строкой $5+3$ с маркированными (акцентируемыми) заключительными слогами каждого сегмента (моры 11112 112). Такой слогоритм, численно превосходящий в ареале все остальные, мы определяем как игровой $5+3$. Текстам с интересующим нас зачином свойственно дробление основных мор (на схеме амплифицированные слоги подчёркнуты):

Стукнула-грукнула: на дварэ,

паглядзі, мамачка, : иі не па мяне.

Неизменное дробление одних и тех же слогов наводит на мысль о заимствовании самого зачина из западной 3-сегментной версии, а для версии-первоисточника не свойственна «теснота стихового ряда» (Ю. Тынянов). Предполагаемая инфильтрация данного зачина в песенную систему Поднепровья сопровождалась, как показывает материал, ритмической «перелицовкой» формулы зачина: редуцировано среднее звено западных зачинов (вараныя/сівыя коні, кованы вазы, жалезныл колы/вушы/кольцыл/калёсы и пр.). Текст принял единую форму, поражающую своей инвариантностью на столь обширной территории. Среди более чем 40 (41) известных нам на данный момент текстов лишь два - периферийные для ареала - лексически отличаются от основного: это смоленский вариант (Ельнинский р-н) Шамкнулі саначкі на дварэ (Грынблат \& Фядосік, 1983, c. 534) и южноминский (Любанский р-н) Стукнула карэта ў варота (Грынблат \& Фядосік, 1983, с. 529).

В днепродвинских зачинах отмечается локально закреплённая фонетическая особенность - замена во вторых слогах глаголов гласного «у» (стукнула, грукнула) на «а» (стукнала, грукнала / стукналі, грукналі. По нашим записям, это минско-могилёвско-витебское пограничье (Борисов, Белыничи, Чашники); возможно, локус в действительности шире, а диалектный гласный «а» ранее не фиксировался либо заменялся во время редакторской правки - в публикациях диалектизм не отражён.

В следующих после зачина строфах содержание варьируется в местных традициях. Существует несколько наиболее часто встречающихся тропов. В большинстве вариантов появляется мотив родительского любования дочерью-невестой перед разлукой (приводим собирательную модель текста):

Стукнула-грукнула на дварэ,

Паглядзі, мамачка, ці не па мяне?

Па ияябе, дзіиятка, па ияябе,

Па твае ясныя вочачкі, па твае русыя косачкі, па твае циіхія паходы, па твае нізкія уклоны. 
Наряду с лирическими, среди текстов с этим же зачином есть и сатирические, с хлёсткими перепалками дочери с матерью, когда речь заходит о размере приданого (Грынблат \& Фядосік, 1983, с. 534-535). К основным стилевым особенностям песен слогоструктурного типа $5+3$ относятся лапидарность ритмики, отсутствие варьирования в виде изоморфных (стопных) подмен в процессе исполнения.

Диахронически два макроареальных ритмосиллабических типа зачинов с единой лексикой отличаются и по своим мелодическим характеристикам. Например, чётко разграничиваются по стилю напевы двух мелоди ко-исторических пластов (мелогоризонтов). В звукоряде терции (более древний пласт) сохранилось большинство напевов с 3-сегментной строкой, как показано на примере зачинов. В звукоряде квинты (более поздний пласт) исполняются восточнобелорусские свадебные песни с той же лексикой зачина ${ }^{7}$. Вокальные стили песен с монотематическим зачином могут существенно отличаться друг от друга, вплоть до полной контрастности; этому в известной мере способствуют просодические свойства интонируемого текста.

Выразительный план рассмотренных песенных зачинов одной группы представляет собой своего рода стихо-вокальную полисемию, симбиоз моносемантики вербального текста и различных по силе и качеству экспрессии мелодических образов. Учёт структурных характеристик песенных зачинов выводит исследование народного песенного творчества на интердисциплинарный этнологический уровень: открываются изодоксы относительно древних певческих стилей и переходные зоны между ними. Интерпретация такого рода данных важна для дальнейшего исследования культурного этногенеза белорусов и их соседей. Динамика и характер преобразований зачинов приоткрывает также аспекты вокально-поэтической антропологии, аксиологии - не декларируемого носителями народного творчества этоса, познаваемого нами через жизненно важные (в данном случае - обрядовые) тексты.

Динамическая типология представляется наиболее гибким и эффективным методом, который можно применять как в синхронических исследованиях всех уровней этнопесенного языка, с определением диалектных градаций внутри системных комплексов текстов, так и при проведении диахронической их таксономизации. Специфика воспроизведения этих текстов в приграничных районах и сам факт, что они здесь сохранились, нередко в исконном - не трансформированном - виде, должно стать темой отдельной публикации.

7 Так называемый рабочий звукоряд включает прилегающие к терции побочные тоны - это опевания активных тонов звукоряда-основы, формирующих типовой инвариант напева, прототип древней модели либо артефакт напева-архетипа. 


\section{Нотный пример 1}
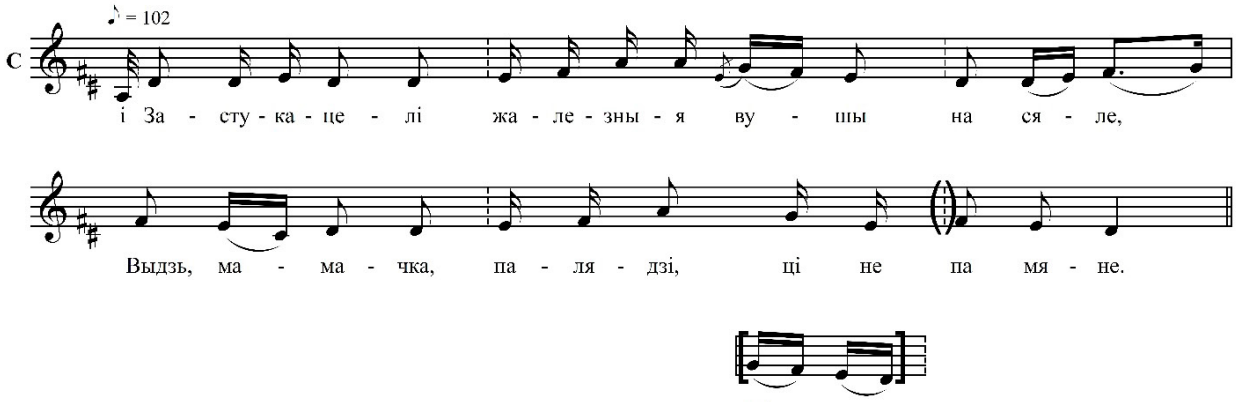

ці не
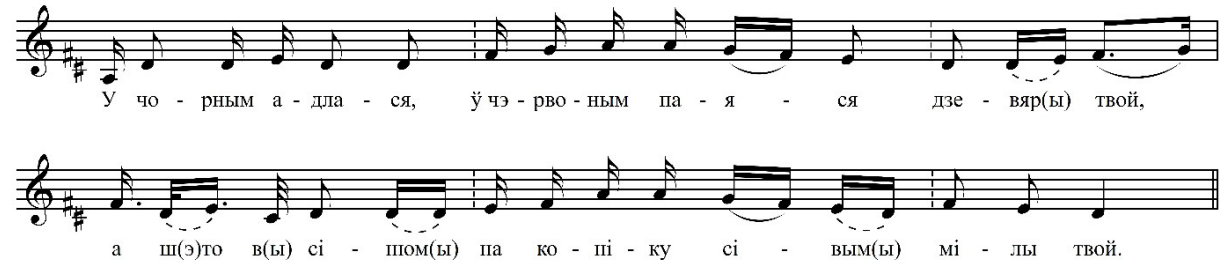

Нотный пример 2

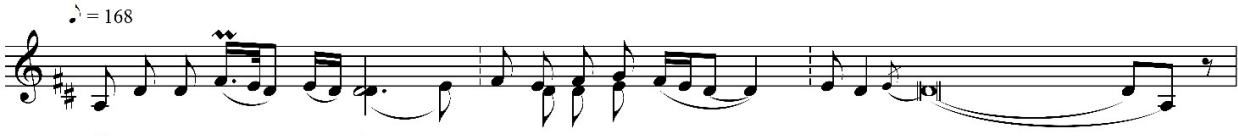

(i) Да за-сту - ка - лі

ко- ва-ны ва - зы

на два - рэ,

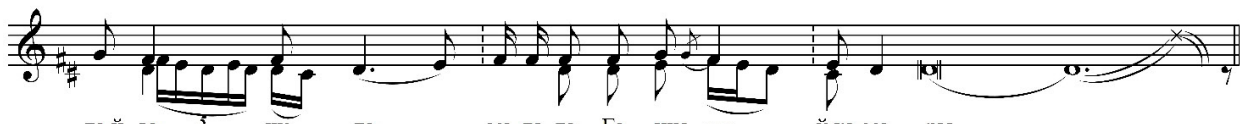

да й за з- чу - ла

ма-ла-да Га - нна-чка

ў ка-мо - ры

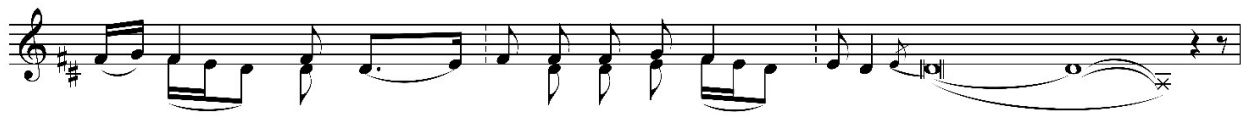

Дай $\mathrm{y}$ - па - ла сва-йму та - та - чку на но - гі:

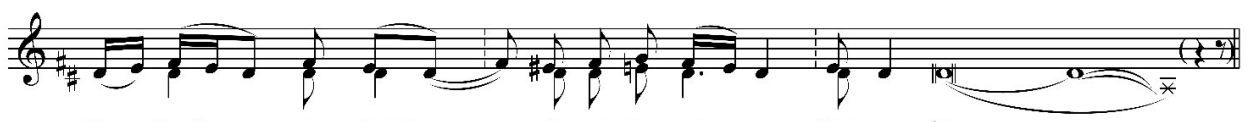

Не 'ддай, не 'ддай, ро-дны та - та - чка,

й ад се - бе! 
КАРТА 1. Монотематический зачин в свадебных песнях 3-сегментной структуры

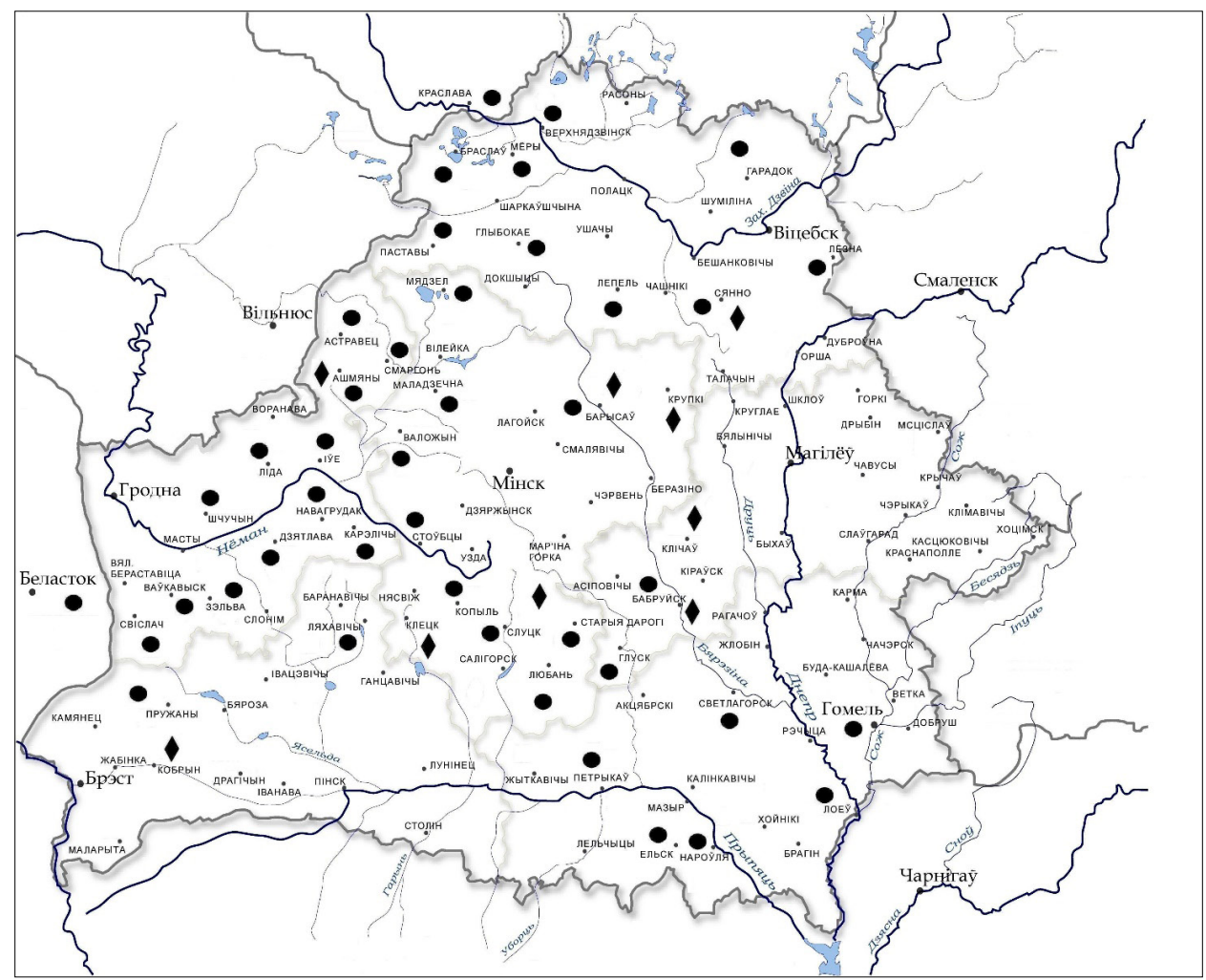

\section{- Основной лексический тип зачина}

Застукалі... / Застукацелі... / Застучэлі...

- Производный лексический тип зачина

Не 'ддай, не 'ддай... 
КАРТА 2. Производный лексический тип зачина Не аддай мяне, мамачка, за ўдайца

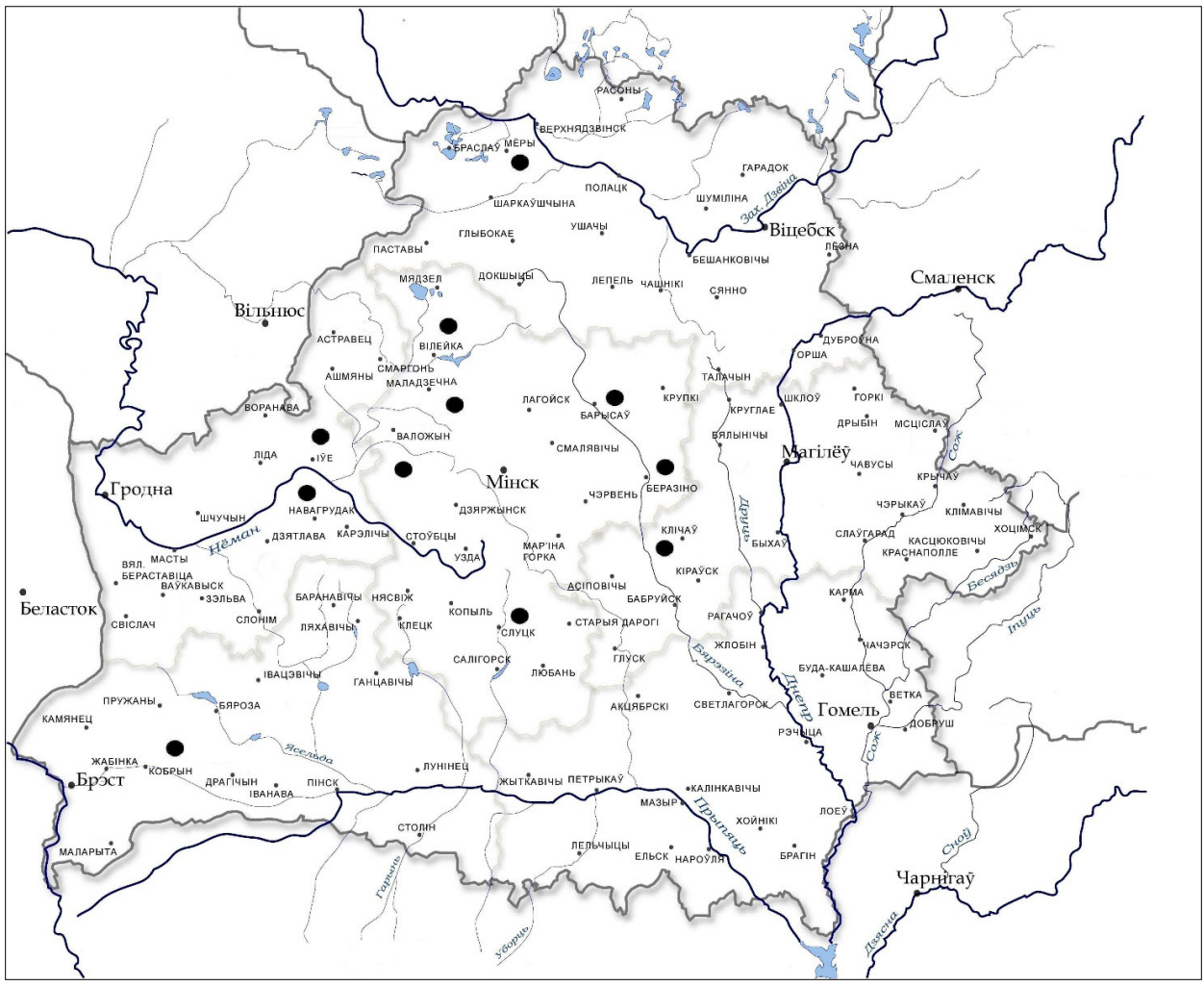


КАРТА 3. Зачин «Стукнула-грукнула на дварэ» в свадебных песнях 2-сегментной структуры игровой слогоритм $5+3$

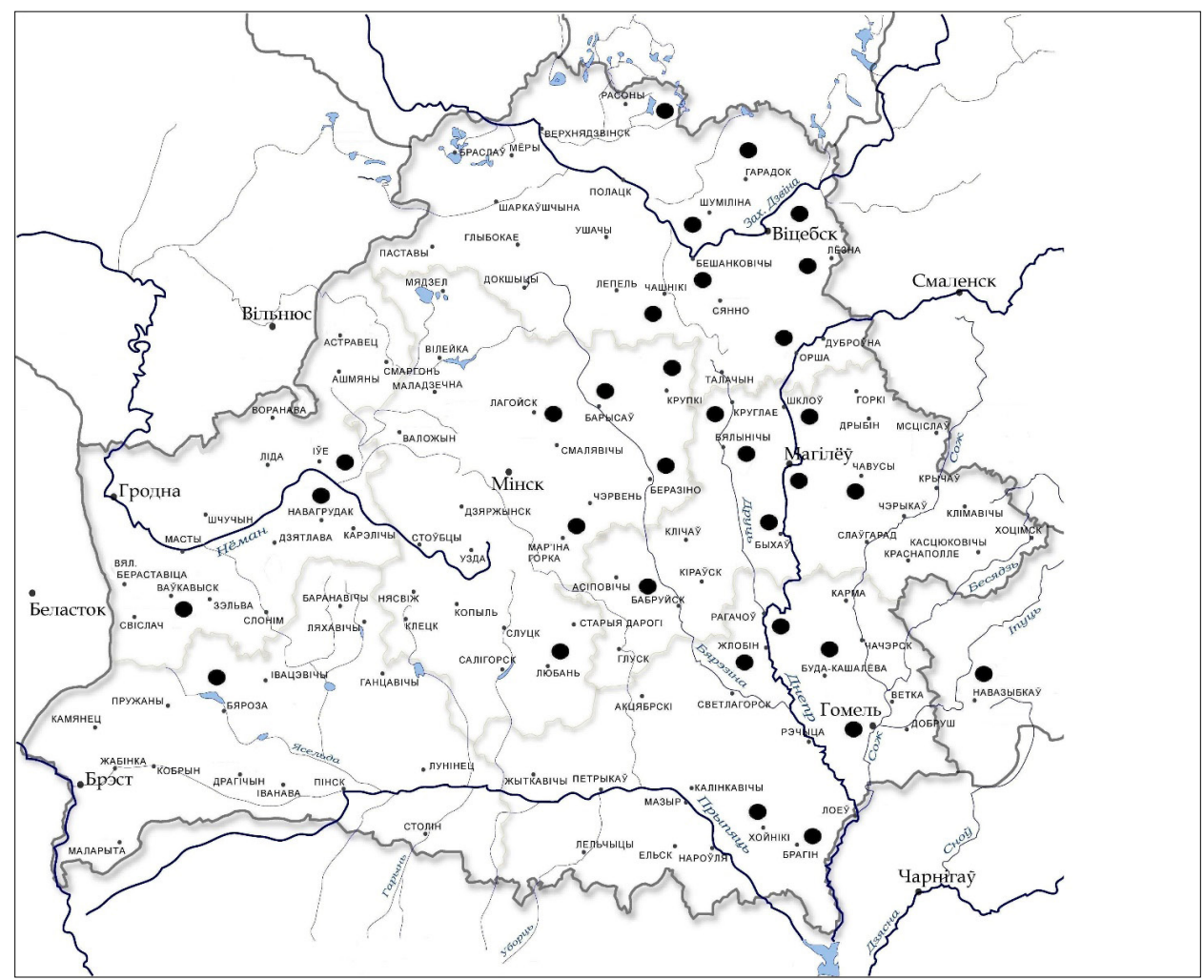




\section{Приложение}

\section{Перечень библиографических источников публикации текстов}

\section{3-хсегментная слоговая структура}

I-1. Зачины, тип «Застукалі вараныя коні на дварэ

Беларускі фальклор 1995: 192, № 268.

Беларускія народныя песні 1959: 18, № 10.

Варфаламеева 1998: 111, № 79.

Вяселле. Песні 1983: 512, 514, 515.

Вяселле. Мелодыі 1990: №№ 243-245, 266, 600, 601, 772, 804, 807.

Захарава 1984: 290, № 218.

Песні Беласточчыны 1997: 163-164, №o 326, 327.

Традыцыйная мастацкая культура 2006: 337-338, № 111.

Традыцыйная мастацкая культура 2012: 519-520, № 171.

Традицийні пісні 2006: 122//142; 123//143-144.

Шырма 1976: 57, № 44; 65, № 51; 66, № 52.

I-2. Зачин, тип «Не аддай, не аддай ...»

Варфоломеева 1988: 110, № 24

Вяселле 1983: 560

I-3. Зачины о вдовце: тип «Не аддай, не аддай ...»

Вяселле 1983: 550-554

Вяселле 1990: 95, № 125

\section{2-хсегментная слоговая структура}

Зачины, тип «Стукнула-грукнула на дварэ»

Анталогія 1975: 98, № 70.

Варфаламеева 1998: 89, № 59.

Вяселле 1983: 512, 513, 515-519, 529, 533-536, 540-543.

Вяселле 1990: 55, № 38; 56, № 39; 503, № 992.

Традыцыйная мастацкая культура 2010: 459-460, № 175. 


\section{Bibliography}

Беларускія народныя песні: Запіс М. Чуркіна. (1959). Мінск: Дзярж. выд. БССР.

Варфаламеева, Т. (1998). Песні беларускага Панямоння. Мінск: Беларуская навука.

Варфаламеева, Т. (Ed.). (2006). Традыцыйная мастацкая культура беларусай: У 6 тамах

(Vol. 3, Гродзенскае Панямонне: У дзвюх кнігах, Кніга 1). Мінск: Вышэйшая школа.

Варфаламеева, Т. (Ed.). (2010). Традыцыйная мастацкая культура беларусай: У 6 тамах

(Vol. 5, Цэнтральная Беларусь: У дзвюх кнігах, Кніга 1). Мінск: Вышэйшая школа.

Варфаламеева, Т. (Ed.). (2012). Традыцыйная мастацкая культура беларусаў: У 6 тамах

(Vol. 6, Гомельскае Палессе і Падняпроўе: У дзвюх кнігах, Кніга 1). Мінск: Вышэйшая школа.

Варфоломеева, Т. (1988). Северо-белорусская свадьба: Обряд, песенно-мелодические типь. Минск: Наука и техника.

Грынблат, М., \& Фядосік, А. (Eds.). (1983). Беларуская народная творчасиь: Вяселле. Песні: У шасиі кнігах (Кніга 3). Мінск: Навука і тэхніка.

Елатов, В. (1966). Ритмические основы белорусской народной музыки. Минск: Наука и техника.

Захарава, А. (Ed.). (1984). Палескае вяселле. Мінск: Універсітэцкае.

Квитка, К. (1973). О природе пауз в народных напевах. In К. В. Квитка, Избранные труды: В двух томах (Vol. 2, pp. 66-80). Москва: Сов. композитор.

Кутырёва-Чубаля, Г. (2013). Этнопесенная лексика как часть культурного наследия былого ВКЛ (Беларусь и приграничья). Acta Baltico-Slavica, 37, 99-119.

Ліцвінка, В. \& Кутырова, Г. (Сотр.). (1995). Беларускі фальклор у сучасных запісах: Традыцыйныя жанры: Мінская вобласць. Мінск: Універсітэцкае.

Традищийні пісні украйниів Північного Підляшщя: За матеріалами експедицій 1999-2001 років Лариси Лукашенко та Галини Похилевич. (2006). Львів: Камула.

Фядосік, А. (Ed.). (1990). Беларуская народная творчасиь: Вяселле, Мелодьі. Мінск: Навука і тэхніка.

Фядосік, А. (Еd.). (1997). Беларуская народная творчасиь: Песні Беласточчыны. Мінск: Беларуская навука.

Цітовіч, Г. (Comp., Foreword, \& Commentary). (1975). Анталогія беларускай народнай песні. Мінск: Беларусь.

Шырма, Р. (1976). Беларускія народныя песні: У 4 тамах: Запіс P. Шырмы (Vol. 4, Вяселле). (Я. Казека, Еd.). Мінск: Дзярж. выд. БССР. 


\section{Bibliography (Transliteration)}

Belaruskiia narodnyia pesni: Zapis M. Churkina. (1959). Minsk: Dziarzh. vyd. BSSR.

Elatov, V. (1966). Ritmicheskie osnovy belorusskoĭ narodnoĭ muzyki. Minsk: Nauka i tekhnika.

Fiadosik, A. (Ed.). (1990). Belaruskaia narodnaia tvorchasts': Viaselle, Melodyi. Minsk: Navuka i tèkhnika.

Fiadosik, A. (Ed.). (1997). Belaruskaia narodnaia tvorchasts’: Pesni Belastochchyny. Minsk: Belaruskaia navuka.

Hrynblat, M., \& Fiadosik, A. (Eds.). (1983). Belaruskaia narodnaia tvorchasts': Viaselle. Pesni: U shastsi knihakh (Pt. 3). Minsk: Navuka i tèkhnika.

Kutyrëva-Chubalia, H. (2013). Ėtnopesennaia leksika kak chast' kul'turnogo naslediia bylogo VKL (Belarus' i prigranich'ia). Acta Baltico-Slavica, 37, 99-119.

Kvitka, K. (1973). O prirode pauz v narodnykh napevakh. In K. V. Kvitka, Izbrannye trudy: $V d v u k h$ tomakh (Vol. 2, pp. 66-80). Moskva: Sov. kompozitor.

Litsvinka, V. \& Kutyrova, H. (Comp.). (1995). Belaruski fal'klor u suchasnykh zapisakh: Tradytsyinyia zhanry: Minskaia voblasts'. Minsk: Universitètskae.

Shyrma, R. (1976). Belaruskiia narodnyia pesni: U 4 tamakh: Zapis R. Shyrmy (Vol.4, Viaselle). (I. Kazeka, Ed.). Minsk: Dziarzh. vyd. BSSR.

Tradytsyini pisni ukraïntsiv Pivnichnoho Pidliashshia: Za materialamy ekspedytsiu 1999-2001 rokiv Larysy Lukashenko ta Halyny Pokhylevych. (2006). L'viv: Kamula.

Tsitovich, H. (Comp., Foreword, \& Commentary). (1975). Antalohiia belaruskă narodnă pesni. Minsk: Belarus'.

Varfalameeva, T. (1998). Pesni belaruskaha Paniamonnia. Minsk: Belaruskaia navuka.

Varfalameeva, T. (Ed.). (2006). Tradytsyı̆naia mastatskaia kul'tura belarusaŭ: U 6 tamakh (Vol. 3, Grodzenskae Paniamonne: U dzviukh knihakh, Pt. 1). Minsk: Vyshëĭshaia shkola.

Varfalameeva, T. (Ed.). (2010). Tradytsyı̌naia mastatskaia kul'tura belarusaŭ: U 6 tamakh (Vol. 5, Tsèntral'naia Belarus': U dzviukh knihakh, Pt. 1). Minsk: Vyshëĭshaia shkola.

Varfalameeva, T. (Ed.). (2012). Tradytsyinaia mastatskaia kul'tura belarusaŭ: U 6 tamakh (Vol. 6, Homel'skae Palesse i Padniaproŭe: U dzviukh knihakh, Pt. 1). Minsk: Vyshëĭshaia shkola.

Varfolomeeva, T. (1988). Severo-belorusskaia svad'ba: Obriad, pesenno-melodicheskie tipy. Minsk: Nauka i tekhnika.

Zakharava, A. (Ed.). (1984). Paleskae viaselle. Minsk: Universitètskae. 


\section{Лексика песенных зачинов в белорусской свадьбе: семантика, структурные трансформации (на примере одной группы текстов)}

\section{Резюме}

В контексте исследования динамической типологии и диалектных признаков белорусской песни мы рассматриваем парадигму текстов белорусской свадьбы, а именно эпизода расставания невесты с родителями. Зачины символизируют момент «вторжения» в жизнь девушки «чужого» рода (рода жениха), имеют единую лексико-поэтическую основу и выражаются формулой «Застукалі кованы вазы на дварэ», существующей во множестве вариантов на обширной территории Беларуси и в приграничьях (Латвия, Польша). Структурные трансформации монотекстовых зачинов выражаются как в редуцировании слоговой структуры, так и в её разрастании (аффиксации). Всё это обусловлено спецификой вокальной ритмики в определённых зонах, преобладанием в ней декламационности либо моторно-соматической динамики. Характерно также разрастание зачинов за счёт добавления сегмента с синонимом-рифмой к начальному слову.

Диахрония текстов данной парадигмы наблюдается также в отсечении типового зачина: песня начинается сразу с кульминационной части текста (эмоциональной реакции молодой на приезд «гостей», обращения к отцу-матери), представляет его фрагмент. В производной парадигме инципитом становится строфа из середины первоначального полного текста. Метод сравнительной динамической типологии применим к различным текстам песен единой структурной основы. Он перспективен в изучении лингво-мелодических диалектов и диахронных изменений в этнопесенном языке белорусов и их соседей.

Ключевые слова: инципит; семантика; трансформация; аффиксация; производная парадигма; динамическая типология 


\section{Leksyka incipitów białoruskich pieśni weselnych: semantyka, transformacje strukturalne (na przykładzie jednej grupy tekstów)}

\section{Streszczenie}

W kontekście badań typologii dynamicznej oraz cech dialektalnych białoruskiej pieśni ludowej rozpatrujemy paradygmat tekstów dotyczących epizodu rozstawania się panny młodej z rodzicami. Są to teksty o tym samym podłożu leksykalno-poetyckim, które charakteryzuje wspólny typ incipitu w różnych jego wariantach. Wszystkie one symbolizują dramatyczny dla panny młodej moment „wtargnięcia” na jej podwórko "obcego" rodu - rodu narzeczonego. Metafora ta zawarta jest $\mathrm{w}$ formule incipitu. Warianty formuły zanotowano na znacznym obszarze Białorusi oraz na terenach przygranicznych (Łotwa, Polska). Transformacje strukturalne tego typu incipitów polegają na redukcji lub rozrastaniu (afiksacji) składu sylabowego wersolinii. Wszystko to jest uwarunkowane semantyką pozawerbalną, wyrażoną przez rytmikę wokaliczną z przewagą albo elementów deklamacyjności, albo dynamiki motoryczno-somatycznej. Charakterystyczne jest również poszerzenie wersu incipitu za pomocą dodawania do początkowego wyrazu synonimu rymowanego.

Diachronia tekstów danego paradygmatu ujawnia się także przy zestawieniu tekstów tematycznie związanych z tymże epizodem wesela. Spora liczba tych tekstów przedstawia wersję skróconą - środkowy i końcowy fragmenty - tekstu pierwotnego danej grupy. Pieśń w wersji skróconej rozpoczyna się od punktu kulminacyjnego, z pominięciem metaforyczno-narracyjnej części wstępnej. Odpowiednio rolę incipitu pełni tu inna strofa. Teksty w wersji skróconej lokalizują się na peryferiach areału. Metodę dynamicznej typologii pieśni stosujemy do opisu tekstów różnych gatunków, o różnej tematyce, jednak należących ściśle do tego samego paradygmatu sylabo-rytmicznego. Otwiera to nowe perspektywy w badaniach dialektów lingwo-muzycznych oraz zmian diachronicznych w języku pieśni ludowej.

Słowa kluczowe: incipit; semantyka; transformacje; afiksacja; paradygmat pochodny; typologia dynamiczna 


\title{
Lexical forms of song's incipits in Belarusian wedding cycle: semantics, structural transformations (an example of one type of texts)
}

\begin{abstract}
In the context of the study on dynamic typology and dialectal features of Belarusian folk songs, the paradigm of texts relating to the episode when the Bride parts with her parents is considered here. Such texts have the same lexical and poetic basis; are characterized by common type of incipit in different variants. All of these texts depict an dramatic for the Bride moment of "intrusion" into her backyard "an alien" family - the Groom's family. Different versions of this incipit have been noticed within the large territory of Belarus and on the frontier (Latvia, Poland). Structural transformations of this type of incipits are manifested by reduction or, quite the opposite, by adding (affixation) syllables in verses. It is conditioned by non-verbal semantics expressed through vocalic rhythmic - the superiority of recitation elements or motor and somatic dynamics. Expansion of an incipit verses by adding to the initial word its rhymed synonym is also a typical phenomena.

Diachrony of a given paradigm texts is also revealed by comparing the texts related thematically to the wedding moment mentioned above. A large number of these texts are abridged versions (a middle and a final part) of full texts of paradigm in question. A song in the abbreviated version begins with the culminative part and omits the metaphorical and descriptive initial part (such transformations can be observed in the periphery districts of a radical area). Accordingly, in such a case a different stanza fulfills the incipit function. The method of dynamic typology is applied while analyzing various texts that belong strictly to the same syllabic and rhythmic paradigm. It is a promising approach to study on linguo-musical dialects and diachronic changes in folk song language.
\end{abstract}

Keywords: incipit; semantics; transformations; affixation; derivative; dynamic typology

Correspondence: Galina Kutyriowa-Czubala, University of Bielsko-Biała (Akademia Techniczno-Humanistyczna w Bielsku-Białej), e-mail: galkut1003@gmail.com

Support of the work: The study was conducted at author's own expense.

Competing interests: The author is a language editor of Russian texts published in this volume of the journal. 